\title{
Prevention of foodborne listeriosis
}

\author{
JM FARBER, PHD, J HARWIG, PHD, A CARTER, MD
}

\begin{abstract}
JM FARBER, J HARWIG, A CARTER. Prevention of foodborne listeriosis. Can J Infect Dis 1991; 2(3):116-120. Listeria monocytogenes is a Gram-positive, rod-shaped bacterium which, although recognized in the medical literature as an opportunistic pathogen for the past 60 years, has only recently gained prominence as an important foodborne pathogen. Factors which make this organism unique among foodborne pathogens include its ability both to survive in foods under a variety of adverse conditions and to grow at low refrigeration temperatures. The organism is very widespread in the environment and can be found in a wide variety of foods. At least four major outbreaks definitively linked to the consumption of food containing $L$ monocytogenes have occurred. In addition there have been a number of recent sporadic cases of listeriosis linked to the consumption of meat, fish and dairy products. The primary concern of the Health Protection Branch is contaminated foods in which $L$ monocytogenes can grow well, and which would not normally be heated prior to consumption. Worldwide, the disease appears to be increasing in incidence, but definite links to foods are difficult to make. In most cases, individuals who come down with listeriosis include the immunocompromised, the elderly (older than 65 years) and pregnant women and their fetuses. Primary manifestations of the disease include meningitis, spontaneous abortion and septicemia. Mortality rates in foodborne listeriosis outbreaks are approximately 30\%. Diagnosis of listeriosis usually requires isolation of the organism from sterile sites such as blood, cerebrospinal fluid, placenta and meconium and gastric aspirates from neonates. The recommended drug of choice is high dose intravenous ampicillin. Advice to physicians concerning measures to prevent foodborne listeriosis in high risk groups is reviewed. Included among these recommendations is avoidance of consumption of potentially hazardous foods such as soft cheese and raw products of animal origin.
\end{abstract}

Key Words: Foodborne, Listeria monocytogenes, Listeriosis, Prevention

\section{Prévention de la listériose contractée par voie digestive}

RESUME: Bien qu'il figure dans la littérature médicale depuis 60 ans à titre d'organisme pathogène opportuniste, Listeria monocytogenes est un bacille à Gram positif qui vient seulement d'être reconnu comme agent pathogène important transmis par les aliments contaminés. Sa capacité de survivre dans les aliments dans toute une variété de conditions adverses et de se multiplier à basses températures distingue cet organisme de tous les pathogènes de ce type. Il est très répandu dans l'environnement et se trouve dans une vaste gamme de produits. Quatre flambées majeures au moins ont été catégoriquement liées à la consommation d'aliments contaminés. De plus, on a récemment noté quelques cas de listériose

Microbiology Research Division. Bureau of Microbial Hazards, Food Directorate, Health and Welfare Canada; Bureau of Communicable Disease Epidemiology. Laboratory Centre for Disease Control. Health and Welfare Canada, Ottawa, Ontario Correspondence and reprints: Dr JM Farber, Microbiology Research Division, Bureau of Microbial Hazards, Food Directorate, Health and Welfare Canada, Ottawa. Ontario K1A OL2. Telephone (613) 957-0895. Fax (613) 957-1907

Received for publication November 8, 1990. Accepted January 28, 1991 


\begin{abstract}
associés à la consommation de viande, de poisson et de produits laitiers. La première préoccupation de la Direction générale de la protection de la santé porte sur les aliments contaminés favorables au développement de $L$ monocytogenes, et qui ne sont habituellement pas réchauffés avant d'être consommés. Partout dans le monde. la fréquence de la maladie semble s'accroître, mais les liens catégoriques avec les aliments restent difficiles à établir. Dans la plupart des cas, les sujets victimes de listériose sont les malades dont les défenses sont compromises, les personnes âgêes de plus de 65 ans, les femmes enceintes et leurs foetus. Méningite, avortement spontané et bactériémie sont les manifestations principales de la maladie. Le taux de mortalité de la listériose contractée par voie digestive atteint près de 30 $\%$. Le diagnostic de listériose requiert habituellement qu'on isole l'organisme des sites stériles - sang, liquide céphalorachidien, placenta et méconium, et échantillons gastriques prélevés chez le nouveau-né. Le médicament de choix recommandé est une dose élevée d'ampicilline par voie intraveineuse. L'article passe en revue les mesures de prévention de la listériose dans les groupes à haut risque. Il recommande notamment d'éviter la consommation d'aliments qui présentent un danger, les fromages mous et les produits crus d'origine animale, entre autres.
\end{abstract}

L ISTERIA MONOCYTOGENES IS AN IMPORTANT FOODborne pathogen which is causing much concern to both food industries and regulatory agencies. This Gram-positive motile bacterium was virtually unknown to the food industry until 1985, when it was found responsible for a large foodborne listeriosis outbreak. In this outbreak, individuals fell ill after consuming a particular brand of Mexican-style soft cheese. In all, 142 people were affected, with 48 deaths. Various other outbreaks linked to foods are listed in Table 1 (1-8).

\section{SPORADIC CASES OF LISTERIOSIS}

In addition to the foodborne outbreaks of listeriosis mentioned above, sporadic cases of listeriosis have been linked through epidemiological and bacteriological studies to foods such as hot dogs (9), undercooked chicken (9), cook-chill chicken (10), vegetable rennet (11), soft cheese (12), alfalfa tablets (12), mother's milk (13), salted mushrooms (14), pâté and fish (15).

\section{MONOCYTOGENES IN FOODS}

The organism, being widespread in nature, has been isolated from a wide variety of foods $(16,17)$. One must generally assume, therefore, that the organism can be present in all foods. In Canada, the isolation rate of the organism from cheese. processed meats and processed fish has been approximately $3.2 \%, 7.3 \%$ and $12.8 \%$, respectively (Health Protection Branch, unpublished data).

\section{FOODS OF CONCERN TO THE HEALTH PROTECTION BRANCH}

Although the number of organisms required to cause clinical disease in apparently healthy or susceptible people is unknown, the majority of foods involved in outbreaks have been those in which $L$ monocytogenes could grow to relatively high numbers. As such, the Health Protection Branch is primarily concerned with contaminated foods in which the organism would be able to grow and which would not normally be heated prior to consumption. Foods perceived by the Health Protection Branch to be of some concern include soft and semisoft cheese, precooked ready-to-eat meats including pâté, and prepared salads with extended shelf-lives. At this time, the most convincing case for a link between large outbreaks of listeriosis and an L monocytogenes-contaminated food has been made for soft cheese. It is difficult to produce this product with a high degree of confidence in its freedom from $L$ monocytogenes,

TABLE 1

Foodborne outbreaks due to Listeria monocytogenes

\begin{tabular}{|c|c|c|c|c|}
\hline Location (year) & Number of cases & Mortality rate (\%) & Foods associated & Reference \\
\hline Boston, Massachusetts (1979) & 20 & 25 & *Raw celery, tomatoes, lettuce & 1 \\
\hline New Zealand (1980) & 29 & 31 & "Shellfish, raw fish & 2 \\
\hline Maritime provinces (1981) & 42 & 41.5 & Coleslaw & 3 \\
\hline Massachusetts (1983) & 49 & 29 & "Pasteurized milk & 4 \\
\hline California (1985) & 148 & 34 & Soft cheese & 5 \\
\hline Switzerland (1983-87) & 122 & 25 & Soft cheese & 6 \\
\hline Philadelphia. Pennsylvania (1986-87) & 36 & 44.4 & *Ice cream, salami & 7 \\
\hline Connecticut (1989) & 9 & 11.1 & ${ }^{*}$ Shrimp & 8 \\
\hline
\end{tabular}

-Foods only epidemiologically associated 
and the ripening process may promote growth of $L$ monocytogenes, if present. Also, the product is handled subsequently at the retail level, thereby providing further opportunity for contamination of the cheese and growth of the organism.

\section{FACTORS UNIQUE TO L MONOCYTOGENES AS A FOODBORNE PATHOGEN}

There are several factors which make this organism unique as a foodborne pathogen. First, the bacterium can grow at low temperatures; therefore, normal refrigeration cannot be relied upon to control its growth (18). L monocytogenes is also widespread in the environment and is known to be a very hardy organism. Concentrations of salt or acid which will usually inhibit the growth of foodborne microorganisms may not inhibit Listeria species (15). In addition, the organism is known to be slightly more heat tolerant than many other vegetative bacteria (19). Although a proper pasteurization process should be sufficient to inactivate any listeriae present (11), foods receiving a minimal heat treatment such as heat-treated cheese or precooked ready-to-eat foods could be of concern. Finally, foodborne listeriosis has been associated with a very high mortality rate, approximately 30\% (20) (Table 1).

\section{INCIDENCE OF LISTERIOSIS IN CANADA}

Prior to 1987, when a surveillance study was initiated by the Laboratory Centre for Disease Control (LCDC), approximately 15 cases of listeriosis per year were reported. In 1987, there were 44 cases with 18 deaths, while in 1988, 60 cases with 20 deaths were reported, a rate of 2.3 cases per million population $(21,22)$. Since 1987 , only two cases have been linked definitively to food through epidemiological and laboratory investigations (22). Reported cases of listeriosis by definition involve invasive disease (mainly septicemia, meningitis or fetal infection), but gastrointestinal symptoms may precede the more serious forms of the disease, or may be the only symptoms of foodborne listeriosis, and therefore go unrecognized $(7,8,20)$. Listeriosis is at present a notifiable disease in only two provinces, but all provinces have agreed informally to look for cases and send information on each case to the LCDC.

In the United States an estimated 1700 cases occur per year, with 450 deaths and 100 stillbirths (20). Worldwide, the disease appears to be increasing in incidence, but links to food are made only rarely, either because they are very difficult to establish or because nonfood sources can be a cause of listeriosis $(20,23,24)$. As an example, in a recent study in the United Kingdom, 24\% of the intermediate and late onset cases of neonatal listeriosis were found to be due to cross infection (24).

\section{CLINICAL LISTERIOSIS}

The primary manifestations of listeriosis include meningitis, spontaneous abortion and septicemia. Peritonitis, local abscess formation, endocarditis, urethritis, endophthalmitis, conjunctivitis, hepatitis, arthritis and cutaneous lesions have also been reported $(20,25)$. Those predisposed to listeriosis include mainly immunocompromised people, the elderly (older than 65 years), and pregnant women and their fetuses. As well, disorders associated with an increased susceptibility to $L$ monocytogenes include alcoholism, diabetes, chronic renal disease and conditions associated with iron overload $(20,25)$. However, it should be noted that listeriosis can occur in normal healthy individuals. The percentage of people in Canada who are predisposed to listeriosis has recently been estimated at 20\% (JM Farber, unpublished data). This latter figure was derived by obtaining annual estimates of the number of individuals in various high risk groups including pregnant women, diabetics, acquired immune deficiency syndrome (AIDS) patients, transplant recipients, cancer patients and those over 65 years of age.

\section{LISTERIOSIS DURING PREGNANCY AND IN NEONATES}

Listeriosis occurs most frequently in the third trimester of pregnancy, but cases have been reported as early as the second month of gestation. The pregnant mother does not usually acquire a fullblown case of listeriosis, but usually presents with a mild 'flu-like illness, including fever, headache and malaise (20). Diarrhea, abdominal cramps and lower back pain, although less common, have also been reported. This prodrome may result in premature labour or septic abortion within three to seven days (20).

Two clinical forms of neonatal listeriosis, early and late onset, are known. The mean onset of symptoms for the former disease occurs at 1.5 days of life, and presumably occurs in infants infected in utero. The disease is known as granulomatosis infantisepticum. In this case the organism is widely disseminated in the body, with lesions most typically found in the liver and placenta. In late onset neonatal listeriosis, the mean onset of symptoms occurs at 14.3 days of life. Meningitis appears to be the predominant symptomatology observed in this form. The source of the organism in late onset cases is unclear at present, although one would suspect that the 


\section{TABLE 2 \\ Health Protection Branch advice to high risk groups regarding foodborne listeriosis}

Avoid consumption of soft cheese

Avoid consumption of all raw products of animal origin

Reheat all leftovers and precooked foods until piping hot,

ie, the temperature in the centre of the food should be at least $74^{\circ} \mathrm{C}\left(165^{\circ} \mathrm{F}\right)$

Just before use, wash all homegrown or store-bought vegetables thoroughly under lukewarm water, while at the same time scrubbing the produce with a brush

Washed and cut vegetables should not be stored for more than one or two days in the refrigerator

Use up any cooked refrigerated leftovers as soon as possible, preferably within two days

Do not buy foods if their 'sell by', 'use by' or 'pull by' dates have expired

infection is either acquired from the mother's genital tract at birth or from environmental sources after birth (20).

\section{DIAGNOSIS}

The diagnosis of listeriosis normally requires isolation of the organism from usually sterile sites such as blood, cerebrospinal fluid, placenta, meconium and gastric aspirates from neonates. Serological tests have not been found to be of value in the diagnosis of the disease (20).

\section{TREATMENT}

The drug of choice for the treatment of listeriosis is high dosage intravenous ampicillin (200 to $300 \mathrm{mg} / \mathrm{kg}$ every $4 \mathrm{~h}$ ), with the recommended duration of therapy ranging from two to six weeks, depending on the clinical syndrome (20). An alternative therapy for patients allergic to penicillin would be trimethoprim plus sulphamethoxazole, or tetracycline for children over eight years of age (20).

\section{ADVICE TO PHYSICIANS}

It is known that $L$ monocytogenes can cause serious illness and death in the fetus and in compromised individuals. The Health Protection Branch recommends that physicians consider the possibility of listeriosis in any febrile nonpregnant patient with neurological symptoms of unknown origin, as well as in pregnant women with unexplained pyrexial illness, miscarriage, premature labour or fetal death. Any patient presenting with any of the above conditions should have appropriate cultures taken, and if $L$ monocytogenes is suspected, antimicrobial therapy should be instituted immediately. It is also recommended that both pregnant women and other groups who are particularly susceptible to infection avoid consumption of soft cheese, reheat all leftovers and precooked foods until piping hot, and wash vegetables very well and then store for no more than one or two days in the refrigerator. A summary of the above recommendations is presented in Table 2. An effective way to reach pregnant women is to present the subject during antenatal visits. The British government has issued guidelines similar to those recommended by the Health Protection Branch, with the additional advice that high risk groups should not eat retail cooked and chilled meals, ready-to-eat cooked poultry, or prepared supermarket salads, as a precautionary measure. The need to reheat cooked foods until piping hot has been particularly emphasized. In addition, women attending routine antenatal clinics in Britain are receiving the warning as a safeguard. At present, the United States has not developed a working document on this subject.

ADDITIONAL INFORMATION: For additional information regarding Listeria monocytogenes in foods, physicians are directed to:

Dr J Farber

Bureau of Microbial Hazards

Health Protection Branch (613) 957-0895

Dr J Harwig

Director, Bureau of Microbial Hazards Health Protection Branch (613) 957-0880

Dr A Carter

Bureau of Communicable Disease Epidemiology Laboratory Centre for Disease Control (613) 957-1339

\section{REFERENCES}

1. Ho JL, Shands KN, Friedland G, et al. An outbreak of type $4 \mathrm{~b}$ Listeria monocytogenes infection involving patients from eight Boston hospitals. Arch Intern Med 1986:146:520-4.

2. Lennon D, Lewis B, Mantell C, et al. Epidemic perinatal listeriosis. Pediatr Infect Dis 1984;3:30-4.

3. Schlech WF III, Lavigne PM, Bortolussi RA, et al. Epidemic listeriosis - Evidence for transmission by food. N Engl J Med 1983:308:203-6.

4. Fleming DW, Cochi SL, Macdonald KL, et al. Pasteurized milk as a vehicle of infection in an outbreak of listeriosis. N Engl J Med 1985;312:404-7.

5. Linnan MJ, Mascola L, Lou XD, et al. Epidemic listeriosis associated with Mexican-style cheese. N Engl J Med 1988;319:823-8.

6. Bille J. Epidemiology of human listeriosis in Europe, with special reference to the Swiss outbreak. In: Miller AJ, Smith JL, Somkuti GA, eds. Foodborne Listeriosis. New York: Elsevier Science Publishers, 1990:71-4, 
7. Schwartz B, Hexter D, Broome CV, et al. Investigation of an outbreak of listeriosis: New hypotheses for the etiology of epidemic Listeria monocytogenes infections. J Infect Dis 1989: 159:680-5.

8. Riedo FX, Pinner RW, Tosca M, et al. A point source foodborne listeriosis outbreak: Documented incubation period and possible mild illness. 30th International Conference on Antimicrobial Agents and Chemotherapy, Atlanta, Georgia, 1990:248. (Abst 972)

9. Schwartz B, Ciesielski CA, Broome CV, et al. Association of sporadic listeriosis with consumption of uncooked hotdogs and undercooked chicken. Lancet 1988;ii:779-82.

10. Kaczmarski EB, Jones DM. Listeriosis and ready-cooked chicken. Lancet 1989;i:549.

11. Kerr K, Dealler SF, Lacey RW. Listeria in cook-chill food. Lancet 1988;ii:37-8.

12. Farber JM, Carter AO, Varughese PV, Ashton FE, Ewan EP. Listeriosis traced to the consumption of alfalfa tablets and soft cheese. N Engl J Med 1990:322:338.

13. Svabic-Vlahovic M, Pantic D, Pavicic M. Transmission of Listeria monocytogenes from mother's milk to her baby and to puppies. Lancet 1988;ii: 1201.

14. Juntilla J, Brander M. Listeria monocytogenes septicemia associated with consumption of salted mushrooms. Scand J Infect Dis 1989;21:339-42.

15. Facinelli B, Varaldo PE, Toni M, Casolari C, Fabio $\mathrm{U}$. Ignorance about Listeria. Br Med J
1989;299:738.

16 Farber JM, Sanders GW, Johnston MA. A survey of various foods for the presence of Listeria species. J Food Protect 1989;52:456-8.

17. Brackett RE. Presence and persistence of Listeria monocytogenes in food and water. Food Technol 1988;42:162-4.

18. Seeliger HPR, Jones D. Genus Listeria pirie. In: Murray RGE, ed. Bergey's Manual of Systematic Bacteriology. Baltimore: Williams and Wilkins, 1986: 1235-45.

19. Farber JM. Thermal resistance of Listeria monocytogenes in foods. Int J Food Microbiol 1989;8:285-91.

20. Gellin BG, Broome CV. Listeriosis. JAMA 1989:261:1313-20.

21. Varughese P, Carter AO. Human listeriosis surveillance in Canada - 1987. Can Dis Weekly Rep 1988;14:151-5.

22. Varughese PV, Carter AO. Human listeriosis in Canada - 1988. Can Dis Weekly Rep 1989; 15:213-7.

23. WHO Working Group. Foodborne listeriosis. Bull World Health Org 1988;66:421-8.

24. McLauchlin J. Listeria monocytogenes, recent advances in the taxonomy and epidemiology of listeriosis in humans. J Appl Bacteriol 1987;63:1-11.

25. Lorber B. Clinical listeriosis - Implications for pathogenesis. In: Miller AJ, Smith JL, Somkuti CA, eds. Foodborne Listeriosis. New York: Elsevier Science Publishers, 1990:41-9. 


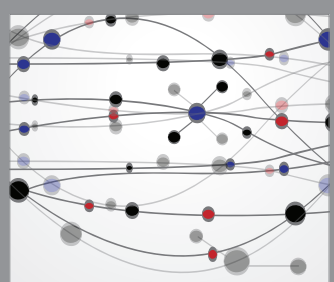

The Scientific World Journal
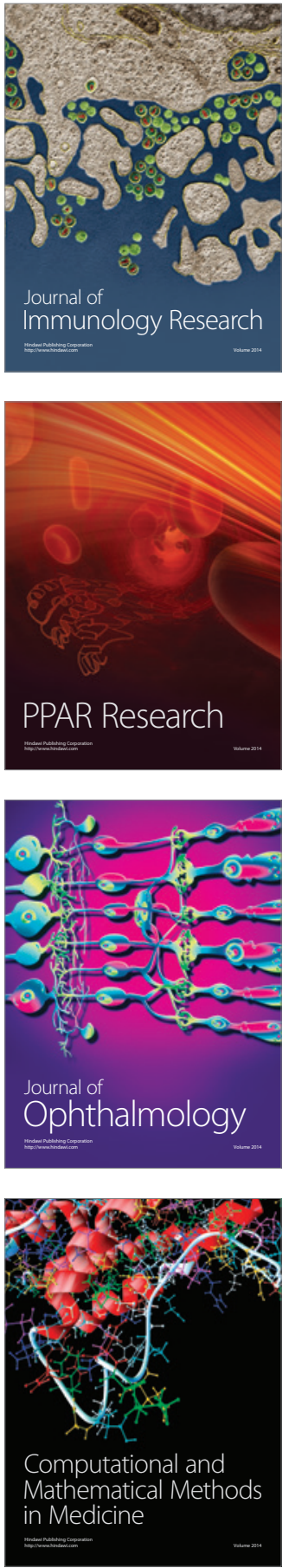

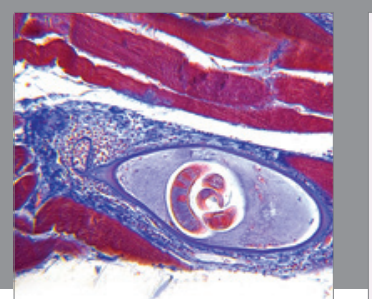

Gastroenterology Research and Practice

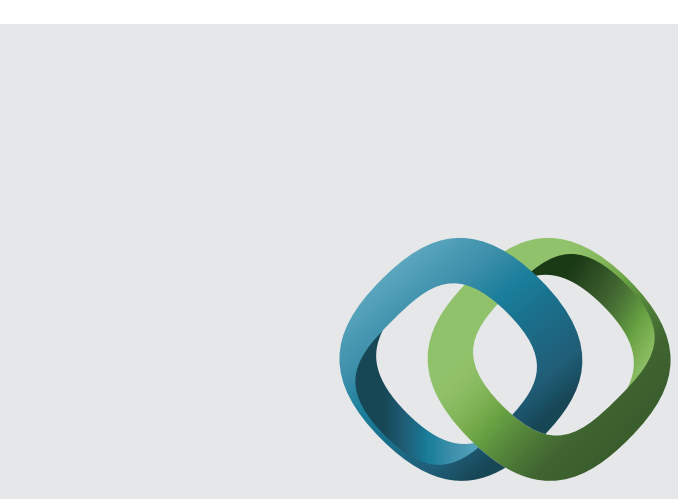

\section{Hindawi}

Submit your manuscripts at

http://www.hindawi.com
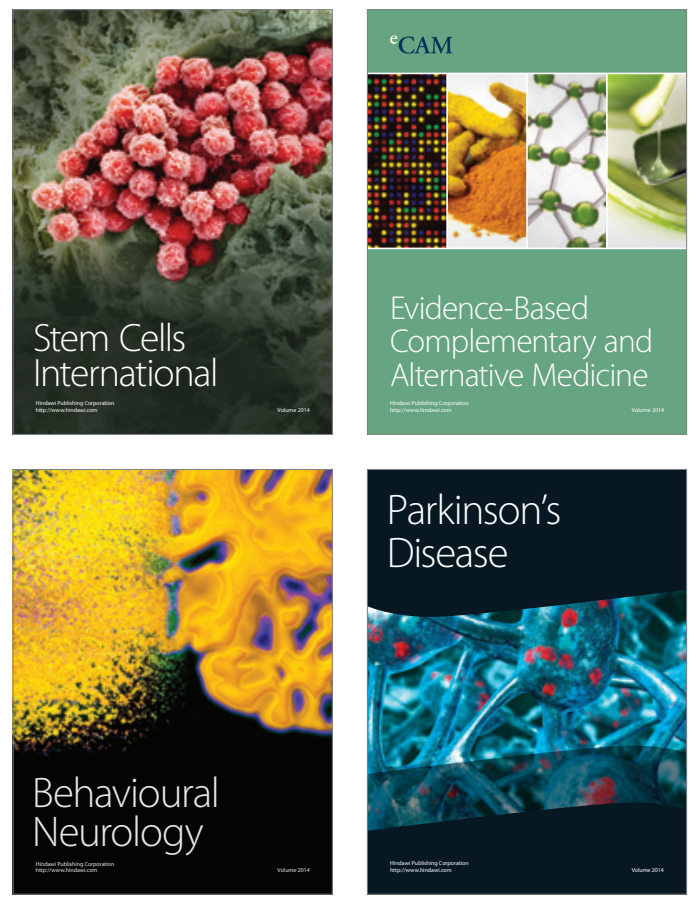
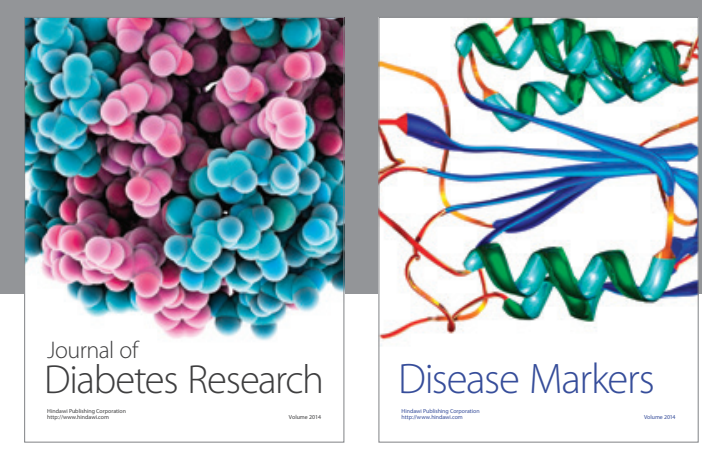

Disease Markers
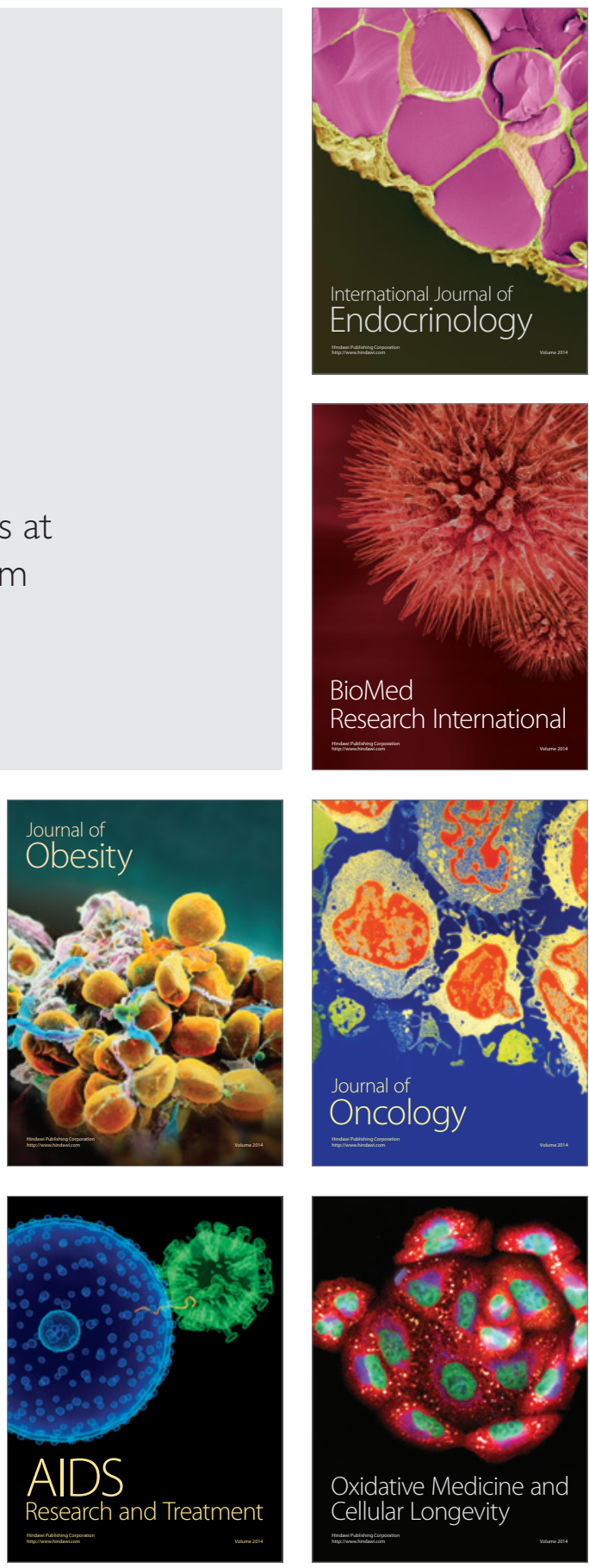